\title{
Artes, Artefatos e Cosmologia entre os Guarani (Nhandeva) em Dourados, Mato Grosso do Sul (Brasil)
}

Rosalvo Ivarra Ortiz

O presente artigo traz informações sobre os Guarani Nhandeva das Aldeia Jaguapirú e Aldeia Bororó, localizadas no município de Dourados, Estado de Mato Grosso do Sul. Este texto busca dar uma visão geral sobre as questões que envolvem arqueologia, história, organização social, política, econômica, com a finalidade de problematizar as produções de artes, artefatos e objetos sagrados e ritualísticos dos Guarani Nhandeva. Portanto, pretende-se dar elementos para uma análise, descrição e interpretação das múltiplas nuances, conceitos ou categorias que envolvem esse coletivo acerca da relação que há entre cultura material e cosmovisão, que na atualidade contemporânea encontram-se numa situação extremamente emblemática, sobretudo a envolver o Yvy (terra).

História, Etnografia, Cosmologia, Cultura material, Guarani Nhandeva.

\section{Guarani: gênese arqueológica e histórica.}

A origem do povo Guarani é bastante emblemática em todos os sentidos, não há uma unanimidade ou um consenso absoluto a respeito da origem, mas as maiorias das investigações arqueológicas e históricas apontam que a etnia ainda como Tupiguarani emergiu nas florestas tropicais dos afluentes do Alto Paraná, Alto Uruguai e nas margens do planalto meridional (Schmitz 1982:57). Assim, no enten-

a Mestrando em Geografia Humana (PPGH/FFLCH/USP). Email: rosalvortiz@ hotmail.com. 
der de Susnik (1982), no século V, provavelmente a cultura Guarani teria se separado do Tupi, seguindo uma lógica própria de existência. Ainda de acordo com Susnik (1982), as populações chamadas de protoguarani que resultaram nos Guarani atuais, vista pela primeira vez no século XVI por não, indígenas, tratando-se dos colonizadores europeus, sobretudo os portugueses. Dessa forma, os principais estudiosos corroboram que desde o princípio os Guarani eram analisados como um povo que não ficam muito tempo num lugar específico, sempre a perambular e migrar-se pelas densas florestas que aqui se encontravam em outrora.

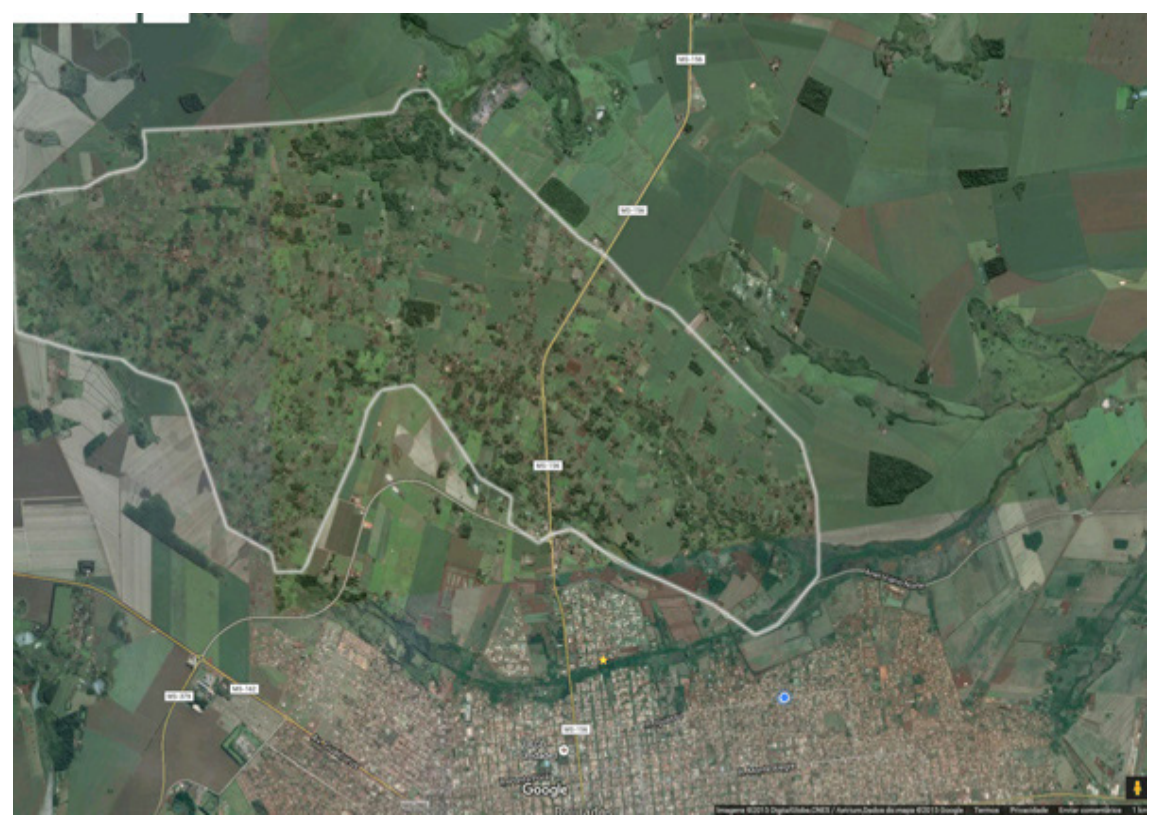

Figura 1. Localização da Reserva Indígenas de Dourados (Mato Grosso do Sul). Fonte: Google, 2019.

De acordo com o arqueólogo jesuíta Pedro Ignácio Schmitz (1982:57), certamente o arqueólogo mais importante e influente no 
Brasil, quando os colonizadores europeus chegaram a 'Nova Terra', o povo Guarani ocupavam uma extensa faixa litorânea que iria desde de Cananeia em São Paulo até o atual Estado de Rio Grande do Sul, adentrando-se pelas bacias dos rios Paraná, Paraguai e Uruguai. Assim, na convergência dos rios Paraguai e Paraná entornavam-se pelas bordas oriental do primeiro e duas margens do Paraná, fronteira com São Paulo, dessa forma, o rio Tietê localizava, se, ao norte e o rio Paraguai ficava a oeste, a demarcar os limites de seus alcances territoriais.

Ainda no entender de Schmitz (1982:57), os dados arqueológicos mostram que nos anos 1000 e 1200 (d. C) estendendo-se a proporção sul, desde das cabeceiras dos rios Paraguai, Araguaia, Xingu e Arinos no oeste do território brasileiro, os Guarani ocupavam o sul do Brasil, norte da Argentina e porção oriental do território paraguaio. Por assim dizer, a partir das chegadas dos colonizadores, especialmente os portugueses e posteriores os espanhóis, a história do povo Guarani foi profundamente marcada pela missão jesuitica, sobretudo a submeter os Guarani ao processo de catequização e doutrinação, onde também marcou o processo que ficou conhecido por encomienda que era uma forma 'legal' de escravizar os indígenas que se encontravam nas Terra Baixas das Américas.

Com o adentramento dos colonizadores na 'Nova Terra', os Tekohá (território Guarani) se tornaram um verdadeiro palco de disputas, onde milhares de vidas foram ceifadas, sangue foram derramados entre as pedras a colorir os rios e riachos, histórias se perderam no tempo, florestas foram devastadas, animais foram aniquiladas, almas de perderam pelos bosques, memórias extinguiram-se para sempre, por fim as farturas se transformam em misérias, fomes e violências. A fauna e a flora que sempre ficaram aos cuidados dos Guarani, agora eram espaços de matança e disputas sangrentas, não somente, pois também eram enxergados pelos colonizadores com estratégias militares, pois a geografia era excelente para coibir a chegada de outro agente, vindos principalmente do 'Velho Continente', que eram vistos como inimigas. 
Ainda de acordo com Schmitz (1982:57), em 1603 o governador do Paraguai enviou uma carta solicitando as presenças dos missionários da Companhia de Jesus, com interesse de catequizar os Guarani que ali se encontravam nesta época, na intenção de inserir na sociedade paraguaia como trabalhador. $\mathrm{Na}$ interpretação de Thomaz de Almeida (1996) esse processo trouxe uma consequência terrível, onde houve dispersões, pois inserir os Guarani forçadamente em diversos aldeamentos construídos pela 'Companhia Aniquiladora', fez com que a população Guarani fosse praticamente aniquilada, onde pouquíssimas resistiram esses cercos. Mas entendo, que nem tudo os que os padres dessa companhia fizeram foram equivocados, pois eles não permitiram que os Guarani fossem escravizados pelos encomenderos de Assunção. Nesse sentido, Gadelha (1999) indaga, que de 1608 a 1768, se constituíram dezenas de reduções jesuiticas, neste período, intitulada de Províncias Paraguaias de Guairá, que abrangeu na época os seguintes territórios: Paraguai, São Paulo e Paraná; Itatim (Mato Grosso do Sul e Paraguai oriental); Paraná (Paraná e Santa Catarina) e a região de Tapés (Santa Catarina, Rio Grande do Sul, Paraguai ocidental e norte da Argentina), demonstrando que a ocupação Guarani era gigantesca.

\section{A organização social Nhandeva}

Em minha investigação, sobretudo com bases em diálogos com várias lideranças como Dona Tereza Guarani Nhandeva, Almires Martins Machado, Dona Maria Guarani Nhandeva, Karai Avá Renato Guarani Nhandeva, Dona Rosangela Guarani, pude confrontar as inúmeras pesquisas que já foram realizadas acerca do povo Guarani com novos dados etnográficos. Dito isso, logo percebi que sua organização social é similar as dos Kaiowá e Mbyá. Dessa forma, os Guarani Nhandeva, ou simplesmente Nhandeva possui sua organização social, política e econômica a família extensa, grupo macro, familiar, constituída por um casal, filhos, irmãos, netos, genros no qual a relação de consanguinidade e afinidade predominam em seu Tekohá (onde 
os Guarani Nhandeva vivem), onde geralmente cada parentela possui uma unidade própria de consumo e produção.

Almires Martins Machado (filho de Guarani Nhandeva com o grupo Aruak Terena), provavelmente o intelectual 'científico' mais importante dessa etnia na atualidade contemporânea, com o qual em várias oportunidade dialoguei e tirei minhas dúvidas, inquietações de dramas do campo, me relatou que os Nhandeva talvez seja o Guarani mais pacífico, pois de acordo com o mesmo sempre age com inteligência, pensa muito antes de fazer ou falar, por isso mesmo em outrora era denominado de filósofo da floresta. Almires me informou que cada grupo ou parentela ou ainda família extensa como a literatura etnológica intitula, é representada por uma liderança geralmente homem, chamado de Tamoy (avô), mas caso seja uma mulher recebe o nome de Jary (avó). Nesse sentido a minha principal interlocutora Nhandeva dentro da aldeia Jaguapirú e Bororó é justamente uma Jary, tratando-se de Dona Tereza Guarani Nhandeva, uma liderança histórica de acordo o professor e historiador Antônio Dari Ramos. Em minha pesquisa, descobri algo realmente incrível e fascinante, que jamais pensei em vivenciar em minha vida, onde apesar de possuir sangue Nhandeva por parte de minha mãe Vitorina Ivarra, minha educação foi distante do Tekohá, mergulhar nesse universo Guarani é único, um verdadeiro sonho.

Kunã Karai Guarani Nhandeva, como é chamada na Aldeia, Dona Tereza me ensinou muitas coisas, uma experiência inesquecível, que levarei para a minha vida inteira. Assim a Xamã, me disse em sua residência, conhecida como Ogapisy, que cabe aos pais e filhos o papel de distribuir as famílias pela comunidade, plantar suas roças, utilizar os recursos disponíveis no ambiente natural, esse contexto familiar é denominado por estudo de parentesco de família nuclear. Portanto, durante a minha estadia na casa de Dona Tereza Guarani Nhande$v a$, percebi que muitas famílias ainda mantém vivas a tradição 'pura' Nhandeva de ser e viver no Tekohá, onde geralmente em cada comunidade há uma casa de reza com um altar chamada de Mba'e Marangatú, 
para a realização do Jeroky Pukú e Jeroky Mimky (dança ou ritual longa e curta), de acorda com Dona Maria Guarani Nhandeva, outra importante liderança pode ser interpretada como os rituais mais importantes e sagrados dos Nhandeva, onde certos objetos são imprescindíveis para realizar as rezas.

Karai Renato Guarani Nhandeva, outra liderança política de grande relevância para os Nhandeva da Reserva Indígena de Dourados (RID) me disse que antigamente os homens (Rajero) casavam, entre 15 e 20 anos, enquanto as mulheres (Kunã) casavam-se a partir da terceira menstruação, por volta de 13 e 15 anos, mas o mesmo me relatou também que esse processo sofreu grande alteração nos últimos anos, sobretudo por influência da sociedade ocidental. De acordo com Dona Rosangela Guarani Nhandeva, uma importante liderança da nova geração, a tradição Nhandeva de outrora, mas ainda mantida viva na atualidade faz que a menina (Mitã Kuña), na primeira menstruação cortasse ou corta o cabelo e mantém resguardada dentro de sua casa $(\mathrm{Og} a)$, por volta de um mês, onde fica impossibilitada de sair, nesse contexto recebe alimento e água.

No que se relaciona ao casamento, os Guarani Nhandeva, de acordo com Dona Maria e Dona Tereza, existem variações a depender exclusivamente da parentela, mas uma coisa é certa, cabe aos pais do rapaz (Ymenarã) entrar em contato e posteriormente se dirigir a residência dos pais da moça (Kunãtãy), pedindo a mão de sua filha (Tajira). Dessa forma, Jaqueline Guarani Nhandeva, que há pouco tempo havia passado por esse processo matrimonial, me indagou que os pais da moça somente aceitam o pedido, caso julga adequado a maturidade do pretendente, sobretudo, ser capaz de gerir uma casa. Jaqueline ainda me disse que para ser aceito, o rapaz jamais pode ter sido reprovado por outros pais anteriormente e nem ser reprovado por má conduta (Tekó Vay) dentro da comunidade Guarani Nhandeva. Para finalizar, me disse que caso, uma Nhandeva vier casar-se com um Kaiowá seria a condenação da família, uma verdadeira desgraça, indagou. Portanto, vejo que há uma relação de animosidade muito grande 
entre os Guarani Nhandeva e Guarani Kaiowá, poucas vezes debatidos e nas maiorias das vezes pouco discutido pelos antropólogos, historiadores, geógrafos, os ditos guaraniólogos. Meu objetivo aqui não é fazer uma descrição densa desse processo, muito pelo contrário, fazer dar informações etnográficas a partir dos objetos 'sagrados' Nhandeva, mas essas questões precisam urgentemente ser debatidos na academia.

De acordo com Almires Martins Machado há uma clareza na divisão do trabalho entre homens e mulheres Guarani Nhandeva, assim cabem aos homens (Rajero ou Karai) preparar a terra, plantar, caçar, pescar; enquanto as mulheres (Kunã) ajudar na roça a escolher sementes, colher os produtos, cuidar da casa, cuidar dos filhos, fazer cestarias, colares, pulseiras, banhar as crianças, dentre outros. Mas muitas atribuições no entender de Almires mudaram, sobretudo pela dinâmica da sociedade capitalista de produção. De acordo com o Almires, posterior ao matrimônio (Omendáhá), o casal vem a constituir uma moradia uxorilocal, isso significa que o conjugues vem a viver na residência dos pais da esposa, onde no primeiro ano, os pais do rapaz passe a ajudar diretamente o filho, sobretudo ajuda econômica, até o mesmo se estruturar no grupo macro familiar e assim passar a constituir uma nova parentela e seguir com a tradição.

Em minha etnografia também percebi um item relevante, onde os cônjuges obrigatoriamente devem pertencer as diferentes parentelas de famílias extensas dispersas pelas comunidades Guarani Nhandeva, ou seja, as regras exogâmicas predominam, no qual há uma proibição veemente procurar cônjuges dentro de um mesmo grupo de parentela ou grupo familiar. Assim, de acordo com Dona Tereza, caso ocorra esse tipo de incesto, conhecido pela denominação de Mbora'u no Tekohá, no futuro acontecerá uma maldição, punição rigorosa de Nhanderú Vussú (o criador na cosmologia Guarani Nhandeva), que poderá condenar a parentela por milhares de anos, com doenças, má formação congênita, onde Mitã (criança) irá nascer com sequelas, deficiências, sem falar, sem audição, sem órgãos sexuais, sem visão, etc. Seria uma verdadeira destruição de acordo com a Xamã Guarani 
Nhandeva, que seria o fim da parentela. Já no caso dos Kaiowá, em conversa com Karai Getúlio Avá Guarani Kaiowá, que foi a primeira liderança a me receber em sua residência em 2017, o que mais preocupa ao grupo é a ideia de poligamia, que caso ocorra, posteriormente irá destruir seu Tekohá, porém, voltando aos Nhandeva, a poligamia não é uma proibição, ainda está presente na tradição.

Portanto, coloco aqui minimante essa situação enfatizando principalmente a rede de parentesco Guarani Nhandeva, que é um sistema extremamente heterogêneo, dinâmico e complexo, pois envolvem muitas categorias sociais, que no meu entender, para compreendemos melhor, seriam necessários mais estudos etnográficos sobre este tema. Porém, genericamente sobre esse assunto, entendo que o Tamoy (avô) e Jary (avó), Nhanderú (guia espiritual homem), Nhandesy (guia espiritual mulher) são os mais importantes, pois através deles que sem mantém a tradição e oralidade Nhandeva ao longo da história. Também verifiquei em minha pesquisa, que os Nhandeva não precisam exclusivamente viver todos juntos, é importante, mas muitos lembram constantemente dos parentes que residem distantes, dessa forma, os vínculos familiares não se perdem, muito pelo contrário, são realçados o tempo inteiro, onde a terminologia Oguatá (caminhar/andar) sempre requisitados entre os Guarani Nhandeva da Aldeias Jaguapirú e Bororó.

\section{Atividades de produção Guarani Nhandeva na RID}

Em minha visita, realizada em 2018, pude perceber que a principal atividade econômica produtiva dos Guarani Nhandeva é a agricultura de coivara, mas, o Karai Renato me disse, "também a gente ama caçar e pescar, mas infelizmente atualmente há poucos recursos na natureza”, finalizou na ocasião. Já Almires Martins Machado me disse que os Nhandeva realizam, principalmente uma atividade de subsistência, onde a distribuição e redistribuição são marcantes nesses processos com um vínculo na rede de parentesco. Assim, a parentela distribui os recursos extraídos da produção por todas as comunida- 
des, sobretudo, por aquelas que não obtiveram tantos sucessos em suas colheitas, isso faz com que os Nhandeva sejam vistos como um povo solidário, os Kaiowá já são diferentes me disse Dona Tereza Guarani Nhandeva. Dessa forma, os Nhandeva compreendem que há Jara (dono) para todos os recursos disponíveis na natureza, por isso mesmo não pode em hipótese algum mesquinhar, me intrigou Jaqueline Guarani Nhandeva.

Em dezembro de 2017, em companhia de Dona Tereza, Almires Martins Machado, Jaqueline Guarani Nhandeva e demais parentes, tive a oportunidade e foi um verdadeiro privilégio visitar as plantações no Tekohá Nhandeva, onde percebi que são espaços bastante significativos, pois eu compreendi, mas pelo que vi são bastante importantes para a compreensão da cosmologia Nhandeva. Na oportunidade Almires me falou sobre a marcação e delimitação, disse que a roça geralmente possui de 1 a 6 ha (hectares) por cada parentela ou unidade familiar. Plantam principalmente milho (Avatí), batata (Jety), mandioca (Mandió), cana (Tanguanre'e), abóbora (Andaí), mamão (Mamone), laranja (Naranrra), banana (Paková), amendoim (Manduví), feijão (Kumandá), arroz (arró), fumo (Penty), remédios (Pohã Nhanã). Dona Tereza me disse na oportunidade ao apontar para a roça "ali está a nossa vida, a nossa existência, a nossa história, a nossa memória”, e por que não, a nossa arte. Almires ainda me relatou, que o Avatí Morontí (milho branco) é diferente do Avatí Sayjú (milho amarelo), o primeiro é sagrado para os Guarani Nhandeva, em que jamais poderá ser comercializada, é um elemento central no ritual Avatí Kiry (batismo do milho).

Mais do que uma atividade apenas ritual e religiosa, a festa do milho novo é o momento de congraçamento e união entre os povos indígenas e membros convidados. É uma maneira de apresentar uma tradição de resistência aos modelos impostos pela sociedade não indígena. De outro modo Geertz nos diz que podemos chamar essas “cerimônias totais de 'realizações culturais' e observar que elas representam não apenas um momento no qual os aspectos conceptuais da 
vida religiosa convergem para o crente, mas também o ponto no qual pode ser melhor examinada pelo observador a interação entre eles" (1989:83). O ritual Avatí Kiry foi recentemente pesquisado por Raul Claudio Lima Falcão no Mestrado em Antropologia da Universidade Federal da Grande Dourados, cuja dissertação traz o título: Avatikyry: o ritual do milho saboró entre os Kaiowa de Panambizinho, Dourados (MS) defendida em 2018.

Por fim, Dona Tereza Guarani Nhandeva me disse na presença de sua filha, conhecida por Nhandesy'i (pequena rezadora), que nesse processo cabe a Kunã (mulheres) a tarefa de pilar o milho e consequentemente preparar a tão famosa Chicha, fazer o Xipákuera (chipa). O milho é um item fundamental, pois através dele pode ser feitos muitas coisas como: farinha (Avatikui), farinha de milho acompanhada de banha de porco (Hu'ikyra Kuré), farinha de milho misturada com mandioca (Hu'i Rovaja Mandió), chipa embrulhada com folhas (Xipá Mbixi), farinha de milho misturada na panela quente (Mbeju), milho assado (Avati Mbixi), milho assado em formato de bolo (Xipa Perõ), milho misturado com batata (Xipa Jetyiru), mingau (Mbaipy), milho ralado (Kãguyjy Miri), pipoca (Avati Pororó), resto de milho (Avatí Kuerreguaré), etc.

\section{Manejo dos recursos ambientais e antrópicos.}

Em minha estadia na Reserva Indígena de Dourados (RID), sobretudo, em ambientes Guarani Nhandeva, pude comprovar que chamado povo Mbaraká Jú possui com a natureza é intrínseca, marcante e histórica, fiquei muito impressionado como eles 'manipulam' os recursos existentes nos ambientes naturais. Dessa forma, o que mais me chamou atenção de imediato, foi o cuidado em manusear a terra, chamado por eles de Ivy. De acordo com Kari Renato Guarani Nhandeva, os Nhandeva usufruem do Tekohá com cautela, pois se caso ofende a terra, Nhanderú não irá gostar, porque ele mesmo deixou a terra para a boa convivência, em hipótese algum poderá destruí-la. Almires disse de uma forma bem simples que, "há algum tempo atrás, vários agrôno- 
mos passaram por aqui, fazendo vários perguntas e se surpreenderam com nós Guarani Nhandeva, principalmente pela nossa organização a envolver o Ivy", que é de uma forma bem dinâmica e estruturada, não faltando absolutamente nada, chamou a nossa técnica de atividade ou manejo de agroflorestal. E isso significa interligar caça, pesca e coleta ao mesmo tempo, sempre tomando em cuidado em não destruir permanentemente os recursos disponíveis, corroborou.

Por fim, percebi que muitos Nhandeva trabalham com vendas, além de vendas de artes como pulseiras, colares, brincos, cestarias coloridas, miniaturas de animais; também comercializam produtos oriundos de roças como mandioca, milho, batata, ovos, frutas, assim vendiam em mercados locais, fora da aldeia de forma ambulantes em carroças e entregas, onde as crianças vão juntas, sempre na presença e um ou mais Jaguá (cachorro) pelas ruas de Dourados (MS). Muitos ainda trabalham em fazendas em arredores dos Tekohá, outros trabalham em prefeituras de cidades vizinhas, além de Dourados, Douradina, Fátima do Sul, Rio Brilhante, Ponta Porã, em muitos casos em situação de vulnerabilidade extrema que ao meu ver passa despercebido pelas autoridades 'competentes'.

\section{Produção e confecção de artes Nhandeva Guarani em Dourados}

Através de etnografias realizadas na Reserva Indígena de Dourados (RID), sobretudo, a partir de conversas com meus interlocutores e protagonistas Nhandeva Guarani, onde tive a oportunidade de acompanhar as coletas, produção e confecção das artes dessa etnia, que também é parte de mim por parte de minha mãe, Vitorina Ivarra, que ainda criança fora retirada dessa comunidade por familiares gaúchos e paraguaios. Destaco que quando criança sempre ouvia a minha mãe mencionar o seu povo, de como eram feitos os objetos de utilização do dia, a dia e processamento de artefatos sagrados, como os casos do Xirú, Mbaraká, Ambá e Takuapú.

Partindo desses pressupostos, gostaria de deixar claro que não concordo com alguns pesquisadores/as que intitulam a produção 
artística Guarani Nhandeva de apenas 'artesanatos'. As artes, artefatos e objetos sagrados Nhandeva ultrapassam essa barreira, vão muito além de ser apenas um elo contemplativo e embelezamento, estão nas memórias, esperanças, sonhos e cosmologia. Dito isso, apresentarei algumas maneiras de desenvolvimento das artes Guarani Nhandeva na Aldeia Jaguapirú e Aldeia Bororó, que são trançados, tecidos, armas, instrumentos musicais, miniaturas e adornos.

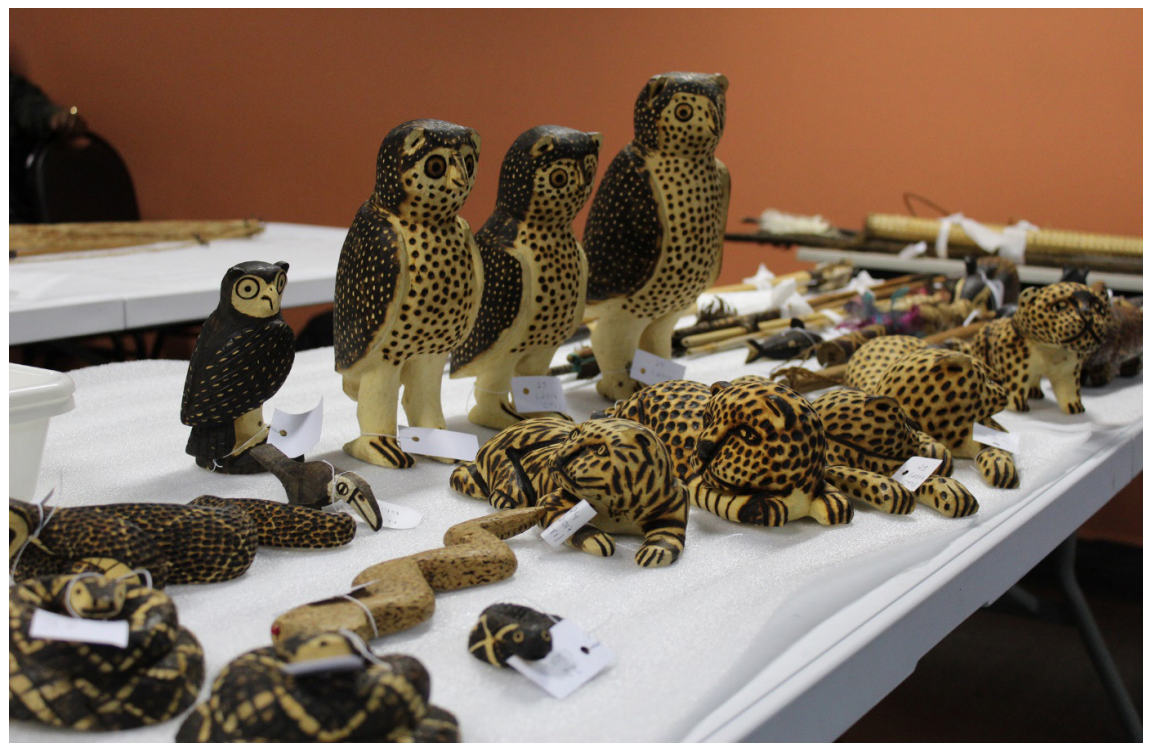

Figura 2. Miniaturas de animais (ressignificações cosmológicas, seguindo uma lógica mecadológica). Fonte: India Vanure, Museu Histótico e Pegagógico, 2019.

\section{Os trançados Nhandeva Guarani}

Berta Ribeiro assinala que os 'trançados' se classificam, segundo suas finalidades, em objetos de uso e conforto doméstico, objetos de caça e pesca, objetos para processamento da mandioca, objetos de transporte de carga e de adorno pessoal (Ribeiro 1988:197). Os tran- 
çados possuem presenças marcante na comunidade, Dona Tereza me diz que eles são os caminhos percorridos por Nhanderú e Nhandesy rumo ao paraíso celestial. Já Paschoalick (2008), enfatiza que o abano servia para atiçar o Tatá (fogo), o cesto possuía a finalidade de inserir frutas como Paková (banana), Araçá (goiaba), Kumandá (feijão), Jety (batata), Manduví (amendoim) e de sementes para plantação, como é o caso de Andai (abóbora). Nesse processo ainda cabe mencionar os cestos, armadilhas para capturar os Pirá (peixes) nos rios que cortam a comunidade, e a peneira chamada de Tipiti, usada na preparação de Mandió (mandioca), também existe o cesto, cargueiro, usado principalmente nos Oguatá Pukú (longa caminhada). Ainda de acordo com a antropóloga, os trançados também serviam de adorno em chapéus, braçadeiras e cintos.

Notei também que as matérias primas mais utilizadas são de procedência de Takuara (bambu), cipó, folhas de palmeiras, fibras de caule, embira de bananeira, sementes de urucum, sangue de animais, sobretudo, aves e animais de caças. Na residência do Nhanderú Karai Avá Jorge da Silva e Kuña Karai Nhandesy Antonia Aparecida, pude observar que eles cultivam as matérias primas no próprio quintal, principalmente pela ausência na RID, causada pela expansão do agrobanditismo, como ele mesmo me disse, acrescentando que muitos artesãos e artesãs sempre buscam recursos em outras aldeias como: Limão Verde, Laranjeira Nhanderú, Panambizinho, Pirakuá, etc. O NhanderúY Alex Souza da Silva que é filho de Jorge da Silva, me disse que utiliza a embira da bananeira produzida na casa de seus pais, para confeccionar cestos a fim de comercializá-los. O Nhanderú Roberto Arce, me relatou que usa o bambu e cipó Guaimbé na produção de trançados, trazida da Aldeia Pirakuá (Bela Vista, MS), e frisou que somente terá sentido se for de Pirakuá, pois é o verdadeiro e original, concluiu.

Em minha visita também pude entender que muitas artes ou objetos deixaram de ser produzidos na Aldeia Jaguapirú e Aldeia Bororó, não por falta de interesse, mas sobretudo, pela escassez gerada pelo 
desmatamento da mata ou floresta que ali estavam, isso já foi bem retratado pela historiadora Paschoalick:

"A cestaria não é muito praticada no momento pelos Kaiowá e isto se deve, sobretudo, pelo fato de não ter mais utilidade no novo modo de ser, tekoyahu, visto que está diretamente relacionada ao transporte por terra de crianças e carga, para uso e conforto doméstico como suporte de cabaça, abanador, esteira, entre outros" (Paschoalick 2008:66).

Durante os dois anos em que empreendi visitas entre os Nhandeva Guarani de Dourados, notei que artes e objetos como cestos armadilhas, cestos cargueiros, gaiolas, tipiti, chapéus, tipoias não foram encontrados. Almires Martins Machado me disse que é imprescindivel realizar pesquisa sobre arte e cosmologia, antes que acabe de vez toda essa história milenar, que se mantem viva, apesar do ataque etnocida dos colonizadores.

\section{A tecelagem Nhandeva Guarani}

Segundo Darcy Ribeiro, tecelagem "é a técnica de interpor regularmente os fios, com ou sem o uso de implementos e aparelhos" (Ribeiro 1988:92). Já para Egon Schaden, os Guarani outrora usam o algodão para confeccionar tecidos. Dessa forma, com o uso do tear, teciam e produziam vestuários masculinos e femininos. Portanto, "fiar, tingir e tecer eram tarefas atribuídas às mulheres" (Schaden 1974 apud Marques \& Alvez 2019:204),. Ao descrever o processo de tecelagem entre as Guarani, Alfred Métraux notou que as mulheres teciam "sem ajuda de nenhum instrumento, passando simplesmente os fios da trama entre aqueles da urdidura como se elas remendassem" (Métraux 2012:322).

Sobre o processo de tecelagem Berta Ribeiro assinala:

"a arte de tecer admite duas macro divisões: trabalho em trama e trabalho em malha. A primeira pressupõe o uso de um dispositivo para a tensão dos fios da urdidura: o tear. E o uso de dois elementos, urdidura e trama ou dois conjuntos de elementos que se entrecruzam formando o tecido. A segunda se processa pelo emprego de um único elemento contínuo de tamanho finito ou infinito, e o uso ou 
não de um implemento, agulha de ponta (tricô), agulha de gancho (crochê) ou agulha de orifício (enlace), ou simplesmente um gabarito" (Ribeiro 1988:92).

Conforme descreve Shaden (1962), com a confecção de tecelagem o povo Guarani produzia tecidos para fazer roupas. A indumentária masculina era formada por ponchito (poncho pequeno), o Txumbé (faixa de algodão usada em torno da cintura) e o Txiripá, pano de algodão de forma retangular, com três lados de franja que desce até abaixo dos joelhos (Marques \& Alves 2019:205). Já a indumentária feminina era composta do Váta, que corresponde a uma blusa, e o Tupái, semelhante a uma saia. Conforme postula Paschoalick (2008), com o uso das fibras de caraguatá (Bromelia antiancatha), planta da família das bromeliáceas, as mulheres Guarani Nhandeva também confeccionavam fios, no qual produziam redes, utilizadas para as crianças dormirem dentro de casa e, também, para o descanso dos homens vindas da roça, caça, pesca e encontros.

Uma coisa que eu percebi em minha visita, já tinha sido também observado pela historiadora Paschoalick, que "pela ausência do algodão e do caraguatá abandonaram a prática de fiar, Povã , [...] [mas] continuam tecendo com barbante, lã, fios de tecidos desfiados, estopa, linha, utilizando a mesma técnica dos seus antepassados" (Paschoalick 2008:68). A artista Guarani Antonia Aparecida faz uso de tear produzido por ela e pelo esposo, o artista Karai Avá Guarani Nhandeva, Admiro Arce, que na ocasião disse que produz em seu quintal o pariri, a cabaça e a bananeira. Assim, com barbante, produzem redes. Já a artista Marilda Duarte elabora faixas e tapetes com o recurso do tear. Portanto, para substituir o algodão, ela utiliza o barbante e a lã, comprados em casas comerciais na cidade de Dourados, como também identificou as pesquisadoras Marques \& Alves (2019). Em minha última visita, pude observar o trabalho de Marilda Duarte Guarani Nhandeva, que informou que as faixas confeccionadas, servem principalmente para produzir saias, ela aplica uma série de sementes nativas, 
dizendo: "isso vai para o mercado, mas leva as nossas memórias, nossas histórias, nossos sonhos”.

\section{As armas Guarani Nhandeva}

De acordo com antropóloga, etnóloga e museóloga brasileira, autoridade em cultura material dos povos indígenas do Brasil Berta Ribeiro, "o conjunto de objetos empregados indiscriminadamente para as funções de guerra e para as tarefas de provimento da subsistência, tais como a caça e a pesca" (Ribeiro 1988:239). Ela também identificou três modelos de armas: armas de arremesso, armas de choque e armas de sopro. Dessa maneira, as armas de arremesso, como a lança, a boleadeira, o arco e a flecha, fornecem subsídios para ataque em pequena, média ou grandes distâncias, usadas, sobretudo para caçar paca, tatu, peixe, quati. Já as armas de choque, como a borduna, se aplicam ao combate próximo ou à caça a animais de grande porte, como anta, veado, queixada, porco do mato. As armas de sopro são aquelas que contêm dardos envenenados, usadas para matar animais ou seres possuídos por espíritos diabólicos (Ribeiro 1988).

A Kuña Karai Tereza Guarani Nhandeva me relatou que a caça e a pesca é própria vida Guarani, disse que Nhanderú Tenondé que a entidade principal na cosmologia Guarani Nhandeva deixou a floresta e os rios para os Guarani viverem em harmonia e em paz, mas que os Karaí estão destruindo tudo, ela relatou ainda que o fim está próximo, que Nhanderú Tenondé Eté já se cansou de ver seu mundo devastado.

A produção de arco e flecha ainda é marcante na RID, sobretudo, como mercadoria, sendo assim resignificado em uma nova dinâmica, sem perder porém a sua essência, principalmente para os compradores que aos adquirem não se importam se foram esses objetos remodelados em uma outra esfera, mas por possuir uma ancestralidade étnico. A maioria dos artistas Guarani Nhandeva tem consciência desse fato, onde dizem "precisamos continuar vivendo". E no entender de Marques \& Alves (2019), o processo de miniaturização é feito justamente para facilitar acomodações dos abjetos nas bagagens dos compradores, 
predominantemente turistas. Já em relação as matérias primas utilizadas na produção do arco e da flecha, Métraux (1987:140) assinala que ambos eram confeccionados com variados tipos de madeira, como a aroeira (Astronium spp.), o pau d'arco (Tecoma af. Conspicua DC), o ipê (Tabebuia sp.), a carnaúba (Jacaranda copaia) e a pupunha (Bactris speciosa), dentre outros.

Com base na recente publicação de Marques \& Alves (2019), podemos perceber a complexidade da produção atreladas as matérias primas dos objetos Guarani, assim as pesquisadoras sintetizam os seguintes postulados:

"Em relação às matérias primas utilizadas, no presente, os artesãos informaram que se servem de madeiras como o aguaí (Thevetia peruviana), o cipó guaimbé (Philodendron bipinnatifidum) e a taquara. Para o trançado do arco são utilizados, além do cipó, o capim braquiária, a linha e o barbante. Já foi mencionado que o cipó guaimbé está extinto na reserva e só é utilizado quando trazido de outras aldeias da região. O caraguatá, quando encontrado, é utilizado para fazer o cordão dos arcos. Na falta do caraguatá, é empregado o barbante. As penas que adornam as peças são de galinhas, tingidas com papel crepom, anilina e outras tintas compradas em casas comerciais da cidade" (Marques \& Alves 2019:207).

Durante as visitas também pude perceber que o caule de palmeira, bambu, cordão de caraguatá, cipó e penas coloridas são as principais matérias primas encontradas na Aldeia Jaguapirú e Aldeia Bororó, as flechas possuem tamanho aproximado de $1,50 \mathrm{~cm}$ como me mostrou a Nhandesy Dona Floriza Guarani Kaiowá no interior de sua casa de reza $(\mathrm{Oga} / \mathrm{Opy})$.

\section{A cerâmica}

Berta Ribeiro também assinalou que a cerâmica é a "arte de confeccionar artefatos com argila submetidos à combustão e alta temperatura" (Ribeiro 1988:30). Em relação às funções dos artefatos em cerâmica na vida dos povos indígenas, Willey (1987) enfatiza que eram confeccionados pelas etnias indígenas como utensílios 
para conservar, preparar e a posteriori consumir alimentos sólidos e líquidos. Muitas peças também tinham função cosmológica e ritualística, como aquelas empregadas como urnas mortuárias. De acordo com Paschoalick (2008), a cerâmica foi imensamente produzida em outrora pelos Guarani, e na atualidade contemporânea tem sido um recurso de grande relevância para identificação étnica em sítios arqueológicos. Atualmente muitos sítios vêm sendo identificados em Mato Grosso do Sul, como demostram os pesquisadores Kashimoto \& Martins:

"Datações arqueológicas obtidas a partir de amostras coletadas na margem sul matogrossense do rio Paraná, o baixo curso do Ivinhema, na atual reserva dos índios Kadiwéu, ou ainda na margem do córrego Lalima, pequeno afluente do rio Miranda, são evidências incontestes da produção de cerâmica arqueológica, Tupiguarani ou Guarani em Mato Grosso do Sul, nos séculos XVI, XVII e XVIII, as quais estratificamente, atestam as sequências ocupacionais a partir de horizontes deposicionais pré-coloniais" (Kashimoto \& Martins 2008:153).

Em minha visita na Reserva Indígena de Dourados, eu não encontrei nenhuma cerâmica e, isso me chamou bastante atenção, no início acreditava que os Guarani Nhandeva ainda produziam cerâmicas como antigamente, sobretudo, por que outras etnias as produzem na atualidade como os Kadiwéu e os Kinikinau. Mediante isso, fui procurar saber, o porquê dos Guarani não produzirem mais esses objetos milenar. Almires me disse que os Nhandeva não encontram mais facilidades para produzi-las e, atualmente possuem outras prioridade, sobretudo, pelo contexto de violências e violações que se encontram. Já o artista Karai Guarani Nhandeva Jorge da Silva me relatou que ainda há várias pessoas na RID que sabem todos os processos de produção da objetos de cerâmica. Frisou ainda que não existem mais madeiras apropriadas ou adequadas para ser retiradas da mata para queimar e posteriormente produzir a cerâmica. Disse que ser for confeccionado de qualquer maneira, a comunidade ou parentela pode ser punida por Nhanderú Eté Tenondé. Já Karai Rena- 
to Guarani Nhandeva me disse que na RID não há lugares adequados para guardar os materiais. Por fim, a historiadora Paschoalick também percebeu isso em 2008: "alguns aspectos podem ter contribuído para esse fato, como o conhecimento do metal, o deslocamento dos indígenas de suas aldeias tradicionais e o confinamento em reservas, o novo modo de viver imposto aos Guarani pela sociedade capitalista contribuiu para o abandono da prática oleira." (Paschoalick 2008:94).

\section{Os adornos}

Para Berta Ribeiro (1988) adornos são objetos utilizados para ornamentar o corpo indígena. Esse processo envolve diversas matérias primas, como recursos vindo da flora, da fauna, minerais e, inclusive, produtos industrializados. Já no que tange a característica étnica, Paschoalick afirma:

"São adereços de uso ritual ou cotidiano e indicadores da condição etária, sexual, social e étnica. São elaborados com materiais de origem vegetal, cabaça, castanhas, bambu, lágrima de Nossa Senhora; animal, pêlos, dentes, ossos, penas; mineral, granito, sílex, entre outros" (Paschoalick 2008:55).

No entender de Marques \& Alves (2019), com esses materiais são produzidos objetos e artes como os colares, os cocares, os Tembetás, as pulseiras, as braçadeiras, as tornozeleiras, as saias, os cintos e os brincos. Ainda nesse sentido as pesquisadoras assinalam:

"De acordo com os artesãos guarani da reserva de Dourados, entre os adornos mais produzidos atualmente estão os colares, as pulseiras, os palitos para cabelo e os brincos. Na confecção desses objetos são empregados a casca de coco, a taquara e variados tipos de sementes de plantas nativas. Podem ser referidas as sementes de pau-brasil (Caesalpinia echinata), de lágrima de nossa senhora (Coix lacryma,job), de pariri (Arrabidaea Chica), de olho de cabra (Ormosia arbórea), de leucena (Leucaena leucocephala), de saboneteira (Sapindus saponária) e de açaí (Euterpe oleracea Mart.)” (Marques \& Alves 2019:209). 
Sobre à substituição de matérias primas para a confecção de colares, Paschoalick afirma que "o cordão no qual passam sementes era tradicionalmente confeccionado de fio de caraguatá, porém agora substituído pelo fio de nylon ou linha" (2008:60). Penas de Riguassú (galinha) também são utilizadas para dar variedades de cores, acrescentadas a anilina e papel crepom. Sobre isso Dona Tereza, Dona Floriza, Dona Antonia, Dona Maria foram unânimes em afirmar que no passado, que as tintas retiradas de plantas nativas, uma delas trata-se de Catiguá (Trichilia emarginata). De acordo com Marques \& Alves, o cacique Jorge da Silva cultiva matérias, primas como a cabaça (Crescentia cujete), utilizada para fazer chocalhos, e o pariri (Arrabidaea chica), empregado na confecção de colares e pulseiras. Quanto às sementes, $\mathrm{o}$ artista Guarani explica que todas devem ser colhidas na lua cheia para não carunchar (Marques \& Alves 2019:210). Nesse sentido, a artista Guarani Nhandeva, que eu encontrei próximo ao Banco do Brasil, área adjacência a praça Antônio João em Dourados, MS, ela procura produzir muitos brincos, isso porque é a arte mais procurada pelas mulheres da cidade e tem que até há encomendar.

\section{Instrumentos musicais}

No entender de Anthony Seeger (1987), celebre etnomusicólogo e antropólogo norte- americano, a musica ou cantar sempre fez parte do repertorio indígenas em todos os sentidos. Já para Darcy Ribeiro "a música e os instrumentos musicais se relacionam a aspectos da organização social e da cosmologia. O rito é invariavelmente, um evento musical” (1987:141). É Berta Ribeiro (1988) quem classifica as músicas/ sons indígenas em quatro grupos: aerofones, cordofones, idiofones e membranofones. Dessa forma, os aerofones são instrumentos que produzem som ou harmonia conforme vibração do ar soprado no interior de um receptáculo, onde há participação marcante dos instrumentos de sopro. Já os cordofones são instrumentos que produzem som mediante a vibração de cordas. É os idiofones são instrumentos sonoros entre os quais se classificam o Mbaraká e o bastão oco de ritmo. É por fim, 
os membranofones são instrumentos dotados de caixa de ressonância. Mediante isso Anthony Seeger indaga:

"Os instrumentos musicais na América do Sul compartilham da importância da música. São tidos, frequentemente, pelos nativos como objetos que incorporam um poder identificado com diversas espécies de espíritos, seres ou grupos de pessoas" (Seeger 1987:174).

Em minha investigação pude notar que as matérias,primas usadas para a elaboração de instrumentos musicais são de origem vegetal, animal e mineral, dentre quais deparei com a madeira, a taquara, o bambu, a cabaça e as sementes nativas. Dona Tereza Guarani Nhandeva me disse que há duas maneiras de se fazer o Mbaraká (chocalho, bastão de ritmo, cabaça), primeiramente para utilizar-se nos rituais e posterior como objetos de vendas ou comercialização. Sobre os cantos Guarani Nhandeva os texto clássico de Jakobson (1959) e Severi (2014) me auxiliaram de maneira significativa, sobretudo os três elementos vinculados a tradução: intralinguística, interlinguística e a transmutada. Dessa forma, os autores postulam:

“A tradução intralinguística ou 'reformulação' é uma interpretação de signos verbais por meio de outros signos da mesma linguagem ", " a tradução interlingual ou tradução adequada é uma interpretação de signos verbais por meio de alguma outra linguagem "e" tradução intersemiótica ou transmutação é uma interpretação de signos verbais por meio de sinais de sistemas de signos não verbais" (Jakobson 1959:233, apud Severi 2014:46).

Apesar de não ser meu objetivo realizar uma investigação acerca da etnomusicologia Nhandeva Guarani, compreendo que seja importante destacar, mesmo que seja de maneira conceitual. Já no entender de Deise Lucy Oliveira Montardo, a principal pesquisadora da etnomusicologia Guarani na atualidade, "os cantos e danças constituem caminhos que permitem aos Guarani o encontro com os seres espirituais, com seus heróis criadores e visitas a aldeias divinas" (Montardo 2018:147). A pesquisadora ainda afirma que os Guarani Nhandeva cantam muitas vogais, o que foi percebido por diversos estudiosos, 
como cantos sem letras, que seria um grande equívoco. Portanto, numa interpretação mais detalhada, dos mesmos cantos executados em dias distintos, percebe-se que os "as, es, is, e os" estão sempre no mesmo momento da melodia (Montardo 2018:147). Por fim, cabe destacar o relato de Dona Tereza Guarani Nhandeva, que o cantar para os Guarani significa renovar a alma, o espírito, conectar-se com as divindades e entidades cosmológicas em múltiplas possibilidades, sobretudo de sonhos, esperanças e memórias. Assim em minha visita, pude deparar em diversos momentos, que na hora da produção das artes, artefatos e objetos os Nhandeva estão cantando.

\section{Olhares (in) conclusos sobre arte e cosmovisão ameríndia}

Nos dias atuais o poder econômico das famílias tem outra fonte geradora de recursos, não se concentram mais nas roças, na produção de alimentos. Hoje está diretamente ligada a um trabalho assalariado de um ou mais membros da família. O homem e a mulher geralmente trabalham fora e, por conseguinte, todos os demais membros da casa que estão aptos a vender sua força de trabalho, nas fazendas ou usinas de álcool, prefeitura e empresas prestadoras de serviços. Os programas de assistência social do governo, assim como o auferido pelos aposentados, contribuem para a renda das famílias. Nesse quadro, muitas mulheres assumiram a chefia da família.

A superpopulação tem inviabilizado a agricultura de subsistência, por falta de espaço físico. A terra se tornou pequena, escassa, ainda há o agravante de que a mesma (e)praguejou e só produzindo se usar as novas tecnologias, como os maquinários agrícolas. As atividades remuneradas têm enfraquecido a rede de solidariedade nas relações de parentesco, já não há reciprocidade, mas sim que parentes próximos trabalham nas roças dos outros parentes que são assalariados, em troca de pagamento, potencializando o uso do dinheiro e do consumo. Hoje formando uma classe dos que têm muito bens ou os parentes 'ricos', estes possuem um bom emprego, são mais escolarizados, têm estabilidade no emprego e que passam a ser assediados pelos que não 
têm quase nada ou os chamados parentes 'pobres'. O capital e o acúmulo de riquezas se convertem em poder político, fomentando intrigas, inimizades, fuxicos, podendo criar um poder paralelo e quase sempre o faz. Isso pode significar o rompimento com lideranças locais, marcado pela avidez do poder aquisitivo, na incessante imitação do modo de vida do não indígena, para parecer moderno e interligado com o mundo exterior, querendo demonstrar prestígio dentro e fora da aldeia.

Assim o indígena não se resigna mais a ser objeto de especulações epistemológicas, acadêmicas e sim reclama o protagonismo político, sua participação no momento de discutir as políticas públicas, é o empoderamento e entendimento de epistemologias para solução de seus novos/velhos problemas.

O 'velho' e o 'novo' convivem nas reservas indígenas, a teia de significados enreda-se no saber local (Geertz 2000), dando forma, fluidez, porosidade, permeabilidade, flexibilidade as fronteiras culturais, reinterpretando, ressignificando, reelaborando a sua cultura, rede social, modo de pensar, ver e agir, conforme a situação o exigir, legitimando-a ou não. O século XXI permite ir muito além do imaginado, tanto que o 'índio de verdade', hoje está nas universidades, faz parte das redes sociais da internet, twitando e trocando informações via facebook, 'netizado'. Continuamos na luta com a esperança de dias melhores são possíveis e estes podem estar próximos, estamos nos empoderando de armas muito mais poderosas do que o velho e bom arco e flecha, que o diga o poder das palavras.

Antropologia da arte, etno-estética, arte etnológica ou ainda histórico etnográfico artístico ameríndio são todos termos usados para descrever o que constitui um estudo antropológico das criações humanas, principalmente nas linguagens da plástica, visual, gestual, musical, histórico e iconográfico (Cóquet 2001). Por assim dizer, o delineamento deste campo particular da antropologia tem imediatamente problemas de definição que revela a variedade de termos que têm sido usados até agora para definir ou contextualizar, e que afeta o objeto 
de sua reflexão chamada torre por sua vez, e de acordo com os tempos, arte 'tribal', 'primitiva', 'tradicional', 'etnológica', 'popular'; tais qualificativos trancaram, no passado. O termo 'antropologia da arte' aborda duas questões complementares, uma relativa aos domínios da expressão considerada, a outra ao que entendemos por arte. Na linguagem cotidiana, a palavra 'arte' é geralmente usada para designar imagens figurativas ou não figurativas, em duas ou três dimensões e conjuntos, de todos os povos do mundo; pois inscreveu uma diferença entre os artefatos utilitários pertencentes à indústria artesanal e outros, onde a marca de um significado adicional social, simbólico, religiosa, estético está presente.

Acredito que a origem maussiana da proposição de que a antropologia da arte é uma teoria da arte que considera objetos como pessoas vivas. Em sua teoria da troca, Mauss analisa benefícios ou presentes como pessoas, ou como suas extensões. Dessa forma, podemos muito bem imaginar que é possível considerar objetos de arte como pessoas. Na verdade, pode-se argumentar que, desde a teoria da troca de Mauss, que é a referência ou o protótipo da teoria antropológica, que seria suficiente para a teoria antropológica da arte construir uma teoria semelhante à de Mauss, mas que se relacionaria com objetos de arte e não com benefícios.

Meu propósito é fazer avançar uma teoria antropológica da arte que se assemelhe a outras teorias antropológicas, não apenas a de Mauss, mas também de muitas outras. Minha principal crítica às teorias da estética intercultural e semiótica da arte etnográfica é que seus princípios estão baseados na estética ocidental e da teoria da arte.

\section{Ritual Nhandeva e relações com os artefatos}

A compreensão de um universo de relações sociais indígenas por meio da análise da pratica de rituais religiosos, nos remete a pensar não apenas em uma direção e sim em uma pluralidade de sentidos, signos, símbolos e conceitos que estão em constante suspensão e que referem a própria experiência vivida representada 
em sua execução; sistemas são construídos e junções entre saberes são necessárias para perpetuação de tradições e conhecimentos, e neste universo de construções e dinamicidades onde vários atores participam no sentido de conectar sentidos, experiências, praticas, que se constituirão em modelos a serem seguidos pelas futuras gerações, a educação se faz presente como uma necessidade de se fazer sentir e se fazer ser social e pertencer a coletividade e para esta contribuir para sua existência. Nesta acepção, conseguimos perceber o ritual como uma espécie de linguagem coletiva, um símbolo representativo de algumas verdades transcendentais, que incorporam uma pratica dinamizada que permeia por uma rede complexa de ações significativas capazes de unir um grupo e convencê-lo por meio de sua eficácia (Mauss 2003). Mais do que um movimento cosmológico de ordem reflexiva e ou contemplativa, "os rituais de uma sociedade ampliam, focalizam, põem em relevo e justificam o que já é usual nela" (Peirano 2002:8).

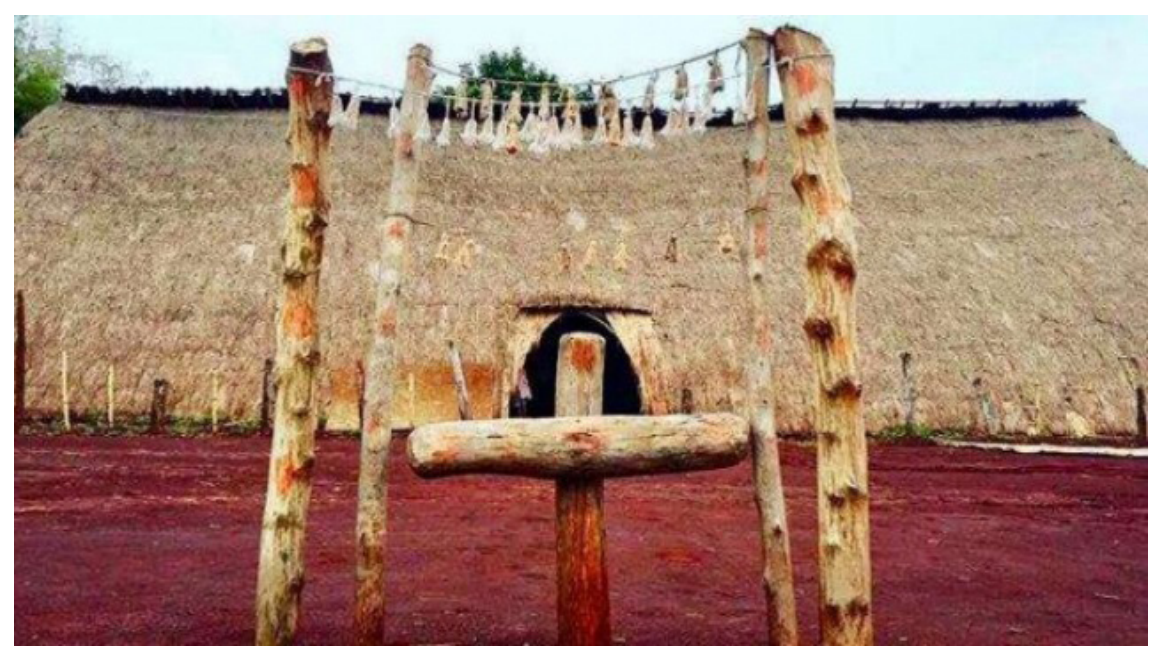

Figura 3. Xirú Kurucú Ambá Guarani em frente de Oga/Opy (casa de reza ou casa ritual). Fonte: Thailla Torres, 2019. 
Dessa forma, começo essa discussão trazendo à tona as palavras de minha guia espiritual Dona Tereza Guarani Nhandeva. Perguntei para ela: a senhora poderia me contar um pouco sobre o Jeroky (a dança ritual). Ela me disse, claro que posso, mas cuidado é longo (risos), eu disse será um prazer, acima de tudo uma honra. Ai ela, então vai. O trecho a seguir é uma adaptação do que a Nhandesy me relatou em sua residência. O Sol vai se pondo no Tekohá, membros de várias parentelas vão chegando com seus apetrechos (Xirú, Mbaraká, Mymby e Takuapú) para passar a noite a dançar no ritmo do Jeroky Pukú (canto,longo), acompanhados de seus filhos vão acomodando-se pela Nhanderogaii (residência Nhandeva), a gritaria/tumulto é total, com as crianças a correr, a rir, outras a chorar; os Jaguá (cachorro) se encontram e se estranham, a provocar em seus donos gritaria para que cada animal retorna a casa. Enquanto não chega a hora, os homens preparam a roda de Teréréiii (bebida típica do Mato Grosso do Sul,similar ao mate gaúcho, mas com adaptação Nhandeva) e as mulheres se juntam aos mesmos ou formam outra roda de Kaá’y (chimarrão ou mate, mais utilizadas pelas mulheres Nhandeva).

Os Nhandeva intitulam a categoria aldeia de Tekohá (também denominados pelos Kaiowá e Pay Tavyterã de Mato Grosso do Sul e Paraguai; Mbyá do Pará, Paraná e São Paulo e o Chiriguano da Bolívia), que é assim que os denominamos, significando para nós lugar para se viver conforme a percepção de Guarani, embora seja do livre arbítrio de cada um viver ou não, conforme tais preceitos; o modo correto de viver conforme ensinado e aprendido nas caminhadas educativas, assim como nas noites de Jeroky (dançar). É o lugar da vida; é a interação do espaço físico com o social, resultando em vida de forma o mais próximo possível ao Raeháxa (tradicional) e não importa onde se esteja, se na terra 'tradicional' ou não, onde se estiver, aí poderá sê-lo; é ali que sua vida literalmente caiu, então deve ser exercitado o ser, para isso não é preciso de um lugar especifico, basta evidenciar o ser, se vai exercitar o Teko Vay (vida má, proceder ruim) ou se o Teko Porã (vida boa, conduta condizente com o modo religioso), isso é com cada 
um, a vida lhe pertence, cabendo somente a ele ou ela conduzir o seu ser, como pude percebe em diversos diálogos.

Mas voltando a Nhandeara ou Oga Guassu, se lá já houver Yvyraîjá (portador do bastão ritual), este já se adianta ao Nhanderú e vai verificando as condições dos instrumentos rituais, se a casa já foi toda varrida, verificado se o pote com casca de cedro vermelho, está cheio de água. Em dado momento o Nhanderú e Nhandesy se levantam, pegam o seu Mbaraká, pigarreia, olha para todos e começa o Jerovassá (abençoar, limpar o corpo), para dar início a dança ritual. Quase sempre acontece de exercitar o seu Mbaraká por um certo tempo diante do Yvyra Marangatu (altar) e o Nhembo'e (oração, encantamento) pode ser ou não audível a todos. Caminha-se pelo terreiro da casa, em círculo, terminando na frente do altar, fechando o formalismo inicial do ritual.

Durante a minha participação do Jeroky Pukú da parentela de Dona Tereza Guarani Nhandeva, que foi realizada em outubro de 2018, percebi que os cantos e as danças executados no ritual Guarani, abrem os caminhos através dos quais os mesmos viajam por e para outras dimensões onde se encontram as aldeias celestes, lá conversam com os ancestrais, com Nhanderú Vussú (nosso Pai/Deus maior), e todos os seres que porventura possam encontrar no caminho dos espíritos, o visível e o invisível se visitam, iniciando o estabelecimento de um futuro parentesco, uma rede social espiritual é formatada.

Almires assinala que é justamente por meio do poder/conhecimento armazenado no Mbaraká ancestral (como se fosse um pen drive), é que o dançarino mestre é guiado por caminhos antes não trilhados ou já conhecidos, dependendo da finalidade da dança ritual, os caminhos pelos quais passará permitem o aperfeiçoamento espiritual. Se for ritual de cura ou ainda para desmanchar feitiços, o proceder ritualístico toma rumos diferentes, conforme o Nhemboe (fala/ encantamento/reza) exigido. Empunhado pelo mestre da cerimônia o Mbaraká se transforma em cetro do poder e o Nhanderú o saber/ fazer/caminhar, exercita-o, fundem-se em um só corpo espiritual, é a agencia que o transporta ao universo não, humano. 
Ao participar de vários Nhemboé (rezas), diálogos com as lideranças Nhandeva, pescas no verão, percebi que o canto e a dança são as linguagens determinadas pelo ritmo dos Mbaraká, que estabelecem o elo espiritual com os lugares celestes, morada de Nhanderu Vussu. As danças seguem marcações rítmicas do maestro Mbaraka Jú aos seus dançarinos, acompanhados pela batida dos Takuapú (bastão rítmico feito de bambu) utilizadas exclusivamente pelas mulheres Guarani. São basicamente dois ritmos na melodia dos Nhanderú/Nhandesy e dos Yayraija, a primeira acelerada e com forte marcação rítmica, marcações para simulações de lutas corporais (como se fora artes marciais); a dança exprime o fervor e fortalecimento religioso; ficar leve facilita a caminhada ao mundo da imaterialidade, é denominada de Jeroky Hatã (dança com marcação acelerada); a segunda é mais lenta, límpida, formal, solene, é denominada de Nheëngaraí ou Jeroky Mbegue, tem a premissa de encantamento, invocação, reverencia, respeito, lamento. No caso das mulheres a movimento do corpo é comumente denominado de Syryry (deslizar) ou Kunã Jeroky (dança feminina Nhandeva); o movimento corporal dos homens produz uma performance pelo terreiro do Ogapysy, é chamado em duas das suas etapas mais usuais de Nhemongu'ê (movimentar-se), e a outra Nhemomisy (agachar-se).

Ao longo de minha jornada juntamente com os Guarani Nhandeva da RID (Reserva Indígena de Dourados), compreendi que se o objetivo é alcançar o Aguyje (perfeição, plenitude), o Kandiré (imortalidade/iluminação), o modo de proceder aqui na terra deve ser irrepreensível, com dedicação ao Purahei (cântico) constante e ao Jeroky; se alcança o Yvã (céu, cosmos), que é em última instancia a morada desejada na eternidade. $O$ grande cuidado é para não errar o caminho que leva ao destino desejado durante o ritual ou a subida, pode ser sem volta; as palavras denotam o seu poder de agir, fazer, transformar, trocar de estado da matéria para o do espírito. Enquanto o Nhanderú (rezador)ou Nhandesy (rezadora) vai seguindo a sua viagem, orientado pelo Mbaraká, ele vai fazendo as suas orações e encantamentos, abrindo as passagens e caminhos, considerando que muitas são as Tava 
(aldeia de pedra) na terra que não se morre mais, sempre haverá a possibilidade de estar indo a um novo Tekohá. Por vezes o cântico/encantamento é audível a todos os presentes no ritual, significando que o caminho é fácil, conhecido, já trilhado, em outros momentos é apenas grunhidos, em razão de estarem sendo usados os encantamentos mais secretos recebidos de Nhanderu Vussú, pois há perigo constante a vista, espíritos malignos à espreita.

Na caminhada em direção a Yvymarane'y pode ter agregado a si outros Guarani, que por ali estejam caminhando rumo a determinado Tekoha; assim como na caminhada terrena no Oguatá (caminhada com intencionalidades), grupos vão sendo constituídos e desfeitos até o ponto de chegada. $\mathrm{O}$ mesmo ocorre na viagem espiritual, pode ser que seja acompanhado de outros Nhanderu ou de espíritos amigos. Esse caminhar define todo um modo de vida e comportamento, dedicação e esforço em estar leve para chegar rápido à rota que conduz ao local almejado. Essa mobilidade tem implicações religiosas, sociológicas e jurídicas, enfatizando a horizontalidade e a verticalidade desses movimentos, considerando a vida terrena e a espiritual.

A Kunã Karai Tereza Guarani Nhandeva, relatou,me que o Guarani precisa cuidar da alma e do corpo, ambas se alimentam e precisam de cuidados, considerando a crença que se possui duas almas: a humana e a animal, deve-se estar sempre atento ao equilíbrio das mesmas, a primeira é lugar da esperança, bondade, realizações profícuas, a segunda é o lugar do mal, do receio, do medo, do desequilíbrio. Assim, na primeira repousa a divindade, razão do esforço para que a mesma tenha garantido o seu lugar na terra, onde não se morre mais, alcançado pelo estado de alma chamado de Aguyjê; na segunda reside maldade, perigo, o risco de ser condenado a ser um espectro que vaga na noite em forma de Anguere ou ser transformado em Jepota.

Agora, Karai Renato Avá Guarani, me disse que o Mbaraká precisa ser exercitado nos locais de origem, os cânticos necessitam alçar os caminhos do céu, a alma precisa ficar leve. Se antes se acreditava que poderia alcançá,la pela via terrestre, rumando-se a leste ou oeste e atra- 
vessando o mar, hoje já se partilha o pensamento que o caminho é o espiritual, para tanto é primordial que tudo volte ao seu lugar de princípio, o território tradicional, juntamente com todos os seus objetos sagrados, de perto e os de longe. Os que tem poder associado ao Mbaraká, os homens, deuses que percorrem constantemente os caminhos do que é designado como Yvã Rapê Jara (caminho do céu), dia após dia persistem no Jeroky, com Takuá e MbarakaY, nesse caminho onde humanos e divindades repousam sob o mesmo teto no Ambá (aldeia celeste), onde exercitam o Ayvu Nhe'ë (fala da alma), considerando os caminhos do céu é possível ver os seus rastos, do leste (Nhandehovái) ao oeste (Nhandekupê).

Para Almires Martins Machado, o grande risco para os iniciantes na caminhada espiritual é se desumanizar, nos confrontos que podem ocorrer nesse meio tempo, em que estão na terra e a caminho do céu. Esses caminhos não são trilhados por qualquer pessoa, é preciso estar de acordo com o Nhandeteko (nosso modo de vida), nesse caso esclareço que o nosso modo de ser é distinto dos demais, abarcando uma ampla gama de elementos constitutivos de vida individual e coletiva, sendo que nessa perspectiva do mundo real, terreno, é manifestamente uma dimensão do que se pode ver, apalpar, medir, sopesar, atitudes, comportamentos coletivos ou não, incluindo regimes alimentares, a esteticidade, redundando na maneira de ver e pensar o mundo e as coisas que nele há. Por essa razão o Guarani considera que seu modo de vida é o correto, porque frequentemente se empodera do modo de ser e viver dos divinos, nas moradas celestes estando em pé e de frente aos mesmos.

Interpretei que proceder expressa-se em ser comedido, calmo, tranquilo, ponderado, solidarizando-se com seu próximo, sempre exercitando a reciprocidade, a temperança, com isso aperfeiçoam os sentidos do corpo como o ouvir, falar, sentir e ver, no entanto o que os diferencia dos demais, é a capacidade de percepção em como proceder para estar cada vez mais próximo de alcançar a perfeição, o Tekó Aguyjê. O cuidado que os Yvyraijá tem durante o Jeroky, se explica 
porque assim como essências aromáticas se fundem a pele, a essência ruim dos invisíveis que estão no caminho espiritual, podem ojá (grudar) na pele do Nhanderú e com ele se fazer presente no Tekohá, a causar males súbitos, doenças, desgraças, a razão de estar alerta e saber o momento certo de passar do Jeroky Hatã, para o Jeroky Mbegüe.

Desviar-se dos caminhos ensinados por este segundo o ensinamento Guarani, manifesta-se em condutas como adquirir os modos dos animais em ser feroz, briguento, avarento, raivoso. Os homens apresentam condutas dos animais, que por sua vez o espírito animal toma a forma de homens. Nessa situação a alma animal sobrepuja a humana. Aprendendo o bem viver e exercitando-o, agrada os que moram no Ambá (Xirú em tamanho maior), dessa forma com as constantes visitações a suas moradas, logo reconhece o Guarani como seu parente e com este estabelece a solidariedade e reciprocidade, indo e vindo descendo e subindo ao Ambá. O visitante então é revestido do Arandu Porã (bom entendimento), essencial para um dia ir de vez para a terra sem mal, sem que para isso passe pela experiência da morte física.

Perante a problemática que envolve o processo de interpretação cultural da nação Guarani, mais especificamente, a nação Nhandeva, entendendo que as práticas rituais se configuram em uma das principais manifestações de um povo, e que a partir destas, podemos caminhar para uma possível construção de uma reflexão sobre o universo das relações sociais formalizadas entre os membros deste grupo, e até mesmo com outros grupos, espaços e posições sociais, pretendi com a realização desta investigação, apresentar apontamento fundamental no tocante aos conhecimentos tradicionais, cosmologia e discutir os artefatos sagrados em diversos contextos acerca desse povo milenar que mantém sua cultura viva ao longo dessa trágica história de violações.

Corroboro ainda que povo Guarani Nhandeva possui muitos saberes míticos que orientam sua organização social, dos quais são transmitidos há outras gerações por meio das histórias contadas e cantadas, o canto exerce importância primaz para sua existência e para a perpetuação de suas tradições, além de garantir a reprodução cultural 
de sua sociedade. Este é ensinado desde a maturidade e realizado para que seja propagado e não haja o fim terreno do povo. Outro elemento importante para entender a organização social Nhandeva e conectar ao processo educacional familiar são os princípios cosmológicos, pois estes se constituem como fator essencial para se entender a origem e a própria concepção de existência do povo Guarani, que mantém relações múltiplas e intrínsecas com os artefatos sagrados e ritualísticos.

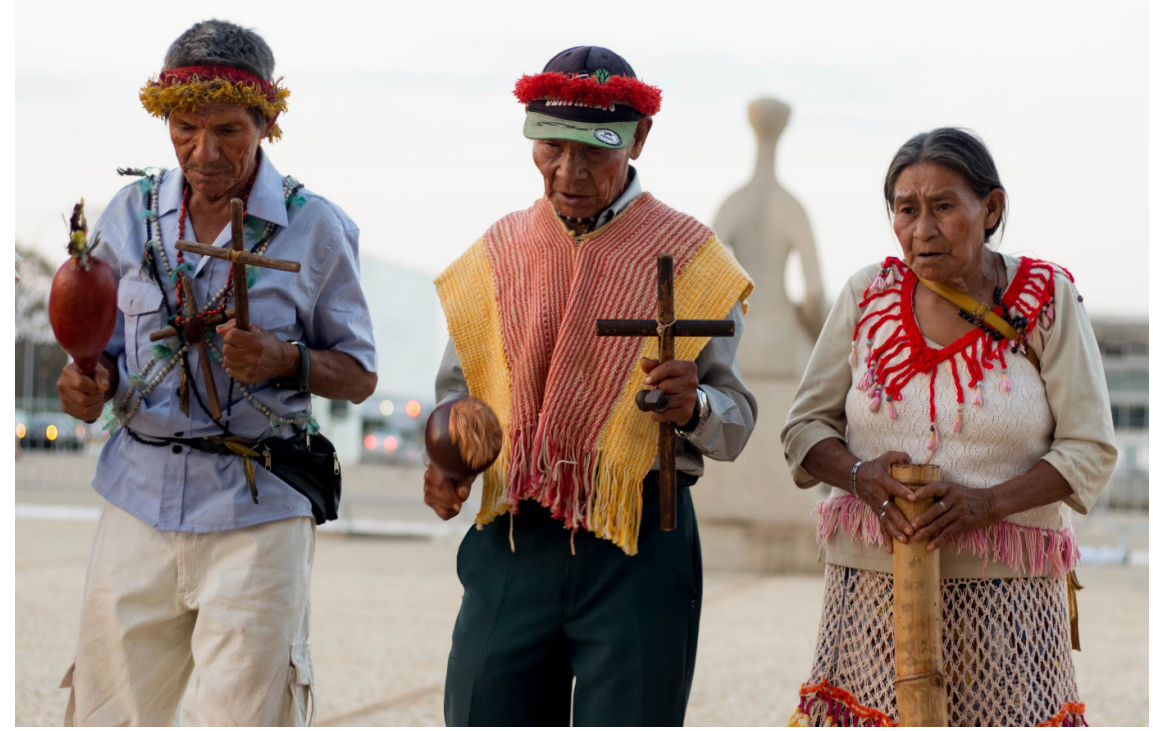

Figura 4. Nhanderú e Nhandesy Guarani portando objetos sagrados em Brasília. Fonte: Tiago Miotto/CIMI, 2017.

Digo ainda que em atenção ao que preconiza Baniwa (2006), percebo que esse processo educacional desenvolvido nas práticas rituais e ampliado pelos mitos e nas tradições orais passadas pelas gerações anteriores é fundamental para a transmissão e produção dos conheci- 
mentos tradicionais indígenas além de se constituir em um importante instrumento de fortalecimento de culturas e das identidades individuais e coletivas. Nesse sentido, cabe falar dos Ivyrá Ijá Kuera (xamã em processo de iniciação, ajudante de Nhanderú e Nhandesy nos rituais). Sendo também um forte elemento constituinte para o estabelecimento de direitos e busca por outros não conquistados ainda ou violados por náo,indígenas ao longo da história. É ao falar de arte, artefato, objeto, agência, eficácia Guarani Nhandeva é trazer à tona as memórias que ainda estão vivas através da materialidade. Ao findar, gostaria de mencionar, por qual motivo utilizei a terminologia ou categoria 'ontografia Guarani Nhandeva', principalmente pelos fatos de os artefatos ou 'objetos' sagrados fazer parte intimamente da vida em comunidade, assim embasa-se na experiencia através das diversas representações que eles são capazes de proporcionar aos grupos ou ainda parentela. Evidentemente que meu objetivo não é fazer uma investigação filosófica, talvez, no máximo uma etnografia ontológica ameríndia.

O que existe entre cosmologia e 'objetos' sagrados Nhandeva e questões de musealização tornam-se pertinentes na concepção Guarani. Pois, deve tratar-se de processos específicos e particulares, uma vez que os artefatos sagrados Nhandeva são usados, sobretudo nos seguintes processos ritualísticos: Jerosy Puku (canto, dança longo), Jerosy Mbyky (canto curto), Nembo'e Kunumi Mboro'yha (ritual de perfuração de meninos afim de acalmar), Nevanga (ritual doméstico, um dos mais antigo que ainda se praticam entre os Nhandeva), Poromotĩha (fazer retroceder algo ou alguém, afim de resolver conflitos internos nas comunidades ou parentelas), Poromondoha (conduzir o/a Nhanderú e Nhandesy para o plano ou terreno espiritual), Nemoeondeha (palavra bem sucedida, encontrar algo buscado como animais, caça e pesca), Nembo'e Nehovaitĩ (ritual de enfretamento, principalmente afim de evitar o suicídio na

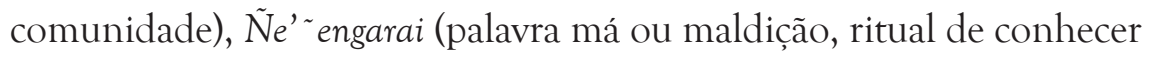
os espíritos malignos para posterior evitar), sempre guiado por um ou uma líder espiritual diferentemente dos Kaiowá e Mbyá. 
Para concluir, gostaria de enfatizar que Umberto Eco e Charles Sanders Peirce foram fundamentais para entender a relação da cosmologia com os objetos, sobretudo ao assinalar que os artefatos sagrados Nhandeva podem ser interpretados como mantenedores de ordem dentro da comunidade (Tekohá). Dessa forma, os 'objetos' Guarani dentro da comunidade pode indicar designação, semelhança, analogia, alegoria, metonímia, metáfora, simbolismo, significação e principalmente comunicação, indo muito além da linguagem, onde signos se entrelaçam nessa complexidade. Peirce (1983), em sua obra intitulada Estudos coligidos fala da concepção tríade do homem, isso também transcorrem entre as artes Nhandeva que passam pela primeiridade, secundidade e terceiridade. Na primeira está a mentalidade do seu produtor/artesão, na segunda está a representatividade e pertencimento e no terceiro está o significado real afim de representar efetivamente o Tekohá Guarani. Dito isso, os objetos, os artefatos ganham vidas e biografias nos ícones (proximidade sensorial e emotiva), índices (representação subjetivo e intersubjetivo) e símbolo, ideias, uma verdadeira lei para os Guarani Nhandeva.

\section{Referências:}

ALMEIDA, Rubem T. 1996. O caso Guarani: o que dizem os vivos sobre os que se matam? In RICARDO, C. A. (ed.): Povos Indígenas no Brasil: 1991/1995, pp. 725-728. São Paulo: Instituto Socioambiental. 2001. Do Desenvolvimento Comunitário à Mobilização Política. O projeto Kaiowa-Nandeva como experiência antropológica. Rio de Janeiro: Contra Capa.

BANIWA, G. 2006. O indio brasileiro: o que você precisa saber sobre os povos indígenas no Brasil de hoje. Brasília: MEC/UNESCO.

BRASIL. 1988. Constituição Federal. Promulgada em 5 de outubro de 1988.

ECO, Umberto. 1988 [1973]. Signo. Barcelona: Labor.

GADELHA, Regina (ed.). 1999. Missões Guarani: impacto na sociedade contemporânea. São Paulo: Edusc.

GEERTZ, Clifford. 1989. A interpretação das culturas. Rio de Janeiro: Livros Técnicos e Científicos Editora S.A. 
GEERTZ, Clifford. 2000. O saber local: novos ensaios em antropologia interpretativa. Petrópolis:Vozes.

JAKOBSON, Roman. 1959. "On Linguistic Aspects of Translation”. In:

BROWER, R. A. (ed.): Translation, pp. 232-239. Cambridge: Harvard University Press.

KASHIMOTO, E. M. \& MARTINS, G. R. 2008. "A problemática arqueológica da tradição cerâmica tupi-guarani em Mato Grosso do Sul”. In PROUS, A. \& LIMÁ, T. A. (eds.): Os Ceramistas Tupiguarani, pp. 149-178. Belo Horizonte: Sigma.

MACHADO, A. M. 2015. Exá raú mboguatá guassú mohekauka yvy marãe"y: de sonhos ao Oguatá Guassú em busca da (s) terra (s) isenta (a) de mal. Tese de Doutorado. Belém: UFPA.

MARQUES, L. \& ALVES, G. 2019. "A produção do artesanato guarani no município de Dourados, Mato Grosso do Sul”. Espaço Ameríndio, 13(1):198216.

MAUSS, Marcel. 2003. Sociologia e Antropologia. São Paulo: Cosac \& Naify

MÉTRAUX, A. 1987. "Armas". In RIBEIRO, D. (ed.): Suma Etnológica Brasileira - v. 2, pp. 139-161. Petrópolis: Vozes.

MONTARDO, Deise. 2018. "Sons e Espacialidade, os Caminhos nos Cantos e Danças Guarani”. Ilha - Revista de Antropologia, 20:145-162.

PASCHOALICK, L. C. A. 2008. A Arte dos Indios Kaiowá da Reserva Indígenas de Dourados, MS: transformações e permanências, uma expressão de identidade e afirmação étnica. Dourados: Editora UFGD.

PEIRANO, Mariza. 2014. "Etnografia não é método". Horizontes Antropológicos, 20(43):377-391.

PEIRCE, Charles S. 1983. Estudos coligidos. São Paulo: Abril Cultural.

RIBEIRO, Berta G. 1988. Dicionário do Artesanato Indígena. São Paulo: Editora da Universidade de São Paulo.

RIBEIRO, Darcy. 1987. Suma Etnológica Brasileira. Atualizada do Handbook of South American Indians. Tecnologia Indígena. Petrópolis: Vozes.

SCHMITZ, Pedro I. 1982. "El Guaraní en Rio Grande do Sul: la colonización del Monte y los frentes de expansión”. Estudos Leopoldenses, 18(64):185-206.

SEEGER, Anthony. 1987. "Novos horizontes na classificação dos instrumentos musicais”. In: RIBEIRO, B. (ed.): Suma Etnológica Brasileira, v. 3, pp. 173, 179. Petrópolis: Vozes.

SCHADEN, Egon. 1974. Aspectos fundamentais da cultura guarani. São Paulo: EDU/ EDUSP.

SEVERI, Carlo. 2014. "Transmutating Beings: A Proposal for an Anthropology of Thought". Hau, 4(2):41-71.

SUSNIK, Branislava. 1982. Los aborigenes del Paraguay. V. 2: Etnohistoria de los Guaranies. Assunção: Museo Etnográfico ‘Andres Barbeiro'. 
Abstract: This article provides information about the Guarani Nhandeva of Aldeia Jaguapirú and Aldeia Bororó, located in the municipality of Dourados, State of Mato Grosso do Sul. This text seeks to provide an overview of the issues involving archeology, history, social political, economic, in order to problematize the production of arts, artifacts and sacred and ritualistic objects of the Guarani Nhandeva. Therefore, it is intended to provide elements for an analysis, description and interpretation of the multiple nuances, concepts or categories that involve this collective about the relationship that exists between material culture and worldview, which in contemporary times are in an extremely emblematic situation, especially the involve the Yvy (land).

Keywords: History, Ethnography, Cosmology, Material culture, Guarani Nhandeva.

Recebido em Outubro de 2019.

Aprovado em Janeiro de 2020. 